\title{
VALIDITAS DAN RELIABILITAS DALAM PENELITIAN KUALITATIF
}

\author{
Yati Afiyanti*
}

\begin{abstract}
Abstrak
Penilaian kualitas suatu temuan penelitian, baik kuantitatif maupun kualitatif memerlukan pembahasan tentang keabsahan data/ validitas (trustworthiness) dan reliabilitasnya. Secara tradisional, penilaian validitas dan reliabilitas dalam penelitian kuantitatif telah memiliki standar baku yang mengacu pada pengujian isi dan kegunaan alat ukur yang dipakai untuk memperoleh data temuannya. Namun, pada penelitian kualitatif, kedua aspek penilaian ini masih menjadi isu yang dipertanyakan, terutama ketika mempertanyakan keilmiahan temuan-temuan metode tersebut. Sesuai pengalaman penulis, aspek validitas dan reliabilitas dapat menjelaskan berbagai teknik operasional yang mendukung rigoritas (ketepatan) data yang dihasilkan dalam penelitian kualitatif, yaitu kredibilitas, dependabilitas, konfirmabilitas, dan transferabilitas.
\end{abstract}

Kata kunci: penelitian kualitatif, reliabilitas, validitas

\begin{abstract}
The quality evaluation in research findings, both of quantitative and qualitative, needs a demonstrated trustworthiness and rigorist. Traditionally, validity and reliability evaluating in quantitative research focus on standardized data collection instruments. However, the validity and reliability in qualitative research, is still a questionable issue, especially when asking about scientific findings of the work. Moreover, both of the validity and reliability describe operational techniques supporting the rigor of the work: credibility, dependability, conformability, and transferability.
\end{abstract}

Key words: qualitative research, reliability, validity

\section{PENDAHULUAN}

Temuan penelitian, baik kuantitatif maupun kualitatif membutuhkan kritik dan evaluasi untuk menilai keabsahan/ kesahihan dan keakuratan data yang dihasilkan. Evaluasi dan kritik dilakukan melalui pengujian validitas dan reliabilitas untuk memperoleh hasil temuan penelitian yang benar yaitu ketepatan data yang dihasilkan. Guba dan Lincoln (1989) menyatakan bahwa paradigma penelitian kuantitatif terdapat empat kriteria untuk menilai keabsahan data yang ditemukan, yaitu validitas internal, validitas eksternal, reliabilitas, dan objektivitas. Keabsahan data temuan penelitian kualitatif ini juga dinilai berdasarkan empat kriteria, yaitu kredibilitas, transferabilitas, dependabilitas, dan konfirmabilitas.

Pengujian validitas dan reliabilitas pada penelitian kualitatif telah memiliki standar baku untuk menilai validitas dan reliabilitas data temuannya melalui pengujian terhadap alat ukur yang dipakai untuk mengumpulkan data.
Sedangkan penelitian kualitatif belum memiliki standar baku untuk menilai kedua aspek tersebut. Dengan demikian, standar baku yang digunakan untuk menilai validitas dan reliabilitas terutama ketika hasil penelitian kualitatif dipertanyakan aspek ilmiahnya menjadi hal penting untuk dibahas (Morse, Barrett, Mayan, Olson, \& Spiers, 2002).

Strauss dan Corbin (1990) menyatakan masih banyak kalangan ilmiah yang kurang memahami paradigma penelitian kualitatif. Ada anggapan bahwa penelitian yang baik harus mampu memenuhi prinsip standar umum penelitian kuantitatif seperti signifikansi, kesesuaian teori dengan data yang ditemukan, generalisasi, konsistensi, kemampuan untuk dibuktikan kembali, presisi, dan verifikasi. Namun, prinsip-prinsip umum tersebut kurang tepat digunakan untuk menilai validitas dan reliabilitas penelitian kualitatif karena penelitian kualitatif mengembangkan prinsip yang berbeda tentang fenomena sosial.

Tulisan ini akan membahas lebih rinci 
tentang elemen-elemen validitas dan reliabilitas dalam penelitian kualitatif, yaitu: kredibilitas, transferabilitas, dependabilitas, dan konfirmabilitas. Berbagai cara untuk meningkatkan validitas dan realibitas penelitian kualitatif juga dibahas dalam tulisan ini.

\section{KREDIBILITAS}

Konsep validitas dalam penelitian kualitatif yang sering digunakan adalah kredibilitas. Kredibilitas menjadi suatu hal yang penting ketika mempertanyakan kualitas hasil suatu penelitian kualitatif. Standar kredibilitas ini identik dengan standar validitas internal dalam penelitian kuantitatif. Suatu hasil penelitian kualitatif dikatakan memiliki tingkat kredibilitas yang tinggi terletak pada keberhasilan studi tersebut mencapai tujuannya mengeksplorasi masalah atau mendeskripsikan setting, proses, kelompok sosial atau pola interaksi yang majemuk/kompleks. Guba dan Lincoln (1989) menambahkan bahwa tingkat kredibilitas yang tinggi juga dapat dicapai jika para partisipan yang terlibat dalam penelitian tersebut mengenali benar tentang berbagai hal yang telah diceritakannya. Hal ini merupakan kriteria utama untuk menilai tingkat kredibilitas data yang dihasilkan dari suatu penelitian kualitatif.

Beberapa aktivitas yang dapat dilakukan peneliti untuk memperoleh tingkat kredibilitas yang tinggi antara lain dengan keterlibatan peneliti dalam kehidupan partisipan dalam waktu yang lama dan berupaya melakukan konfimasi dan klarifikasi data yang diperoleh dengan para partisipan/member checks (kembali mendatangi partisipan setelah analisis data) atau melakukan diskusi panel dengan para ekspertis/ahli untuk melakukan reanalisis data yang telah diperoleh (peer checking). Aktivitas lainnya yaitu melakukan observasi secara mendalam juga perlu dilakukan sehingga peneliti dapat memotret sebaik mungkin fenomena sosial yang diteliti seperti adanya.

Hall dan Stevens (1991) mengungkapkan hal yang sama bahwa untuk memperoleh validitas internal/ kredibilitas yang tinggi terhadap data yang dihasilkan, peneliti harus melakukan aktivitasaktivitas antara lain membina hubungan/ rapport yang mendalam, mengakrabkan diri dengan setting penelitian, dan memiliki sensitivitas yang kuat terhadap bahasa dan gaya hidup para partisipannya. Dengan melakukan aktivitas-aktivitas tersebut, data yang diperoleh akan menggambarkan dengan tepat tentang pengalaman hidup partisipan, yang dapat dikenali oleh partisipan itu sendiri dan akan memiliki kredibilitas yang tinggi. Selanjutnya, penulis harus menuliskan laporan hasil temuannya dengan penjelasan mendalam tentang aspek-aspek dengan variabel dalam penelitian kuantitatif yang saling berkaitan dan interaksi dari berbagai aspek lainnya. Penyusunan laporan tersebut menjadi salah satu ukuran kredibilitas penelitian kualitatif.

\section{TRANSFERABILITAS}

Transferabilitas merupakan istilah yang dapat menggantikan konsep generalisasi data dalam penelitian kuantitatif, yaitu sejauh mana temuan suatu penelitian yang dilakukan pada suatu kelompok tertentu dapat diaplikasikan pada kelompok lain (Streubert \& Carpenter, 2003; Graneheim \& Lundman, 2004). Dalam penelitian kuantitatif, istilah transferabilitas merupakan modifikasi atau mendekati istilah yang sama dengan validitas eksternal yang pada kenyataannya, hal ini sulit dicapai. Generalisasi hanya dapat dicapai bila obyek studi dapat dilepaskan sepenuhnya dari pengaruh konteks penelitian, suatu hal yang nyaris mustahil dilakukan dalam penelitian kualitatif (Patton, 1990).

Transferabilitas penelitian kualitatif tidak dapat dinilai sendiri oleh penelitinya melainkan oleh para pembaca hasil penelitian tersebut. Jika pembaca memperoleh gambaran dan pemahaman jelas tentang laporan penelitian (konteks dan fokus penelitian), hasil penelitian itu dapat dikatakan memiliki transferabilitas tinggi (Bungin, 2003; Morse, Barrett, Mayan, Olson, \& Spiers, 2002). Istilah keterwakilan (representasi) dan generalisasi didekati secara berbeda dalam penelitian kualitatif dan perlu diperhatikan dalam hal pengambilan 
sampel untuk memungkinkan diterapkannya hasil penelitian kualitatif pada kelompok lain.

Pengambilan sampel pada penelitian kualitatif tidak didasarkan pada teori probabilitas seperti halnya yang dilakukan pada penelitian kuantitatif. Prosedur pengambilan sample penelitian kualitatif dilakukan secara teoritis (theoretical sampling) atau dilakukan secara sengaja (purposive sampling). Untuk itu, peneliti kualitatif perlu memberi perhatian pada saat melakukan seleksi pengambilan sampel. Pengambilan sampel sebaiknya dititikberatkan pada unit-unit esensial dan tipikal dari karakteristik subyek yang diteliti dan unit-unit teoritis tersebut ditentukan sesuai dengan pemahaman konseptual terhadap subyek atau topik yang diteliti. Dengan demikian, acuan generalisasi diarahkan pada kasuskasus yang menunjukkan kesesuaian konteks, bukan dalam kerangka prinsip acak.

\section{DEPENDABILITAS}

Istilah reliabilitas dalam penelitian kualitatif dikenal dengan istilah dependabilitas. Konsep reliabilitas ini juga sering manjadi pertimbangan lain dalam menilai keilmiahan suatu temuan penelitian kualitatif. Pertanyaan mendasar berkaitan dengan isu reliabilitas adalah sejauh mana temuan penelitian kualitatif memperlihatkan konsistensi hasil temuan ketika dilakukan oleh peneliti yang berbeda dengan waktu yang berbeda, tetapi dilakukan dengan metodologi dan interview script yang sama.

Ada dua sumber pengertian tentang reliabilitas dalam paradigma penelitian kuantitatif yaitu mengartikan reliabilitas sebagai suatu konsistensi atau konstansi dari suatu alat ukur (Morse, Barrett, Mayan, Olson, \& Spiers, 2002) dan reliabilitas sebagai ukuran suatu alat ukur mengukur suatu atribut yang telah dirancang untuk mengukurnya (Polit \& Hungler, 1995). Dari definisi tersebut, pemahaman tentang reliabilitas suatu penelitian mengacu pada standarisasi alat ukur yang digunakan dalam penelitian tersebut.

Tingkat dependabilitas yang tinggi pada penelitian kualitatif dapat diperoleh dengan melakukan suatu analisis data yang terstruktur dan berupaya untuk menginterpretasikan hasil penelitian dengan baik sehingga peneliti lain akan dapat membuat kesimpulan yang sama dalam menggunakan perspektif, data mentah, dan dokumen analisis penelitian yang sedang dilakukan (Streubert \& Carpenter, 2003). Melalui konstruk dependabilitas, peneliti memperhitungkan perubahan-perubahan yang mungkin terjadi menyangkut fenomena yang diteliti, juga perubahan dalam desain sebagai hasil pemahaman yang lebih mendalam tentang setting yang diteliti.

Brink (1991) menyatakan ada tiga jenis uji/tes yang dapat dilakukan untuk menilai reliabilitas/ dependabilitas data penelitian kualitatif yaitu: stabilitas, konsistensi, dan ekuivalensi. Stabilitas dapat dinilai/ diuji ketika menanyakan berbagai pertanyaan yang identik dari seorang partisipan pada waktu yang berbeda menghasilkan jawaban yang konsisten/sama. Selanjutnya, konsistensi dapat dinilai jika interview scripts atau daftar kuesioner yang digunakan peneliti untuk mewawancarai partisipannya dapat menghasilkan suatu jawaban partisipan yang terintegrasi dan sesuai dengan pertanyaan/topik yang diberikan. Terakhir, ekuivalensi dapat diuji dengan penggunaan bentuk-bentuk pertanyaan alternatif yang memiliki kesamaan arti dalam satu wawancara tunggal dapat menghasilkan data yang sama atau dengan menilai kesepakatan hasil observasi dari dua orang peneliti.

Upaya peneliti untuk meningkatkan nilai dependabilitas data penelitian kualitatifnya diantaranya adalah melakukan pemilihan metode penelitian yang tepat mencapai tujuan-tujuan penelitian yang diinginkan. Selanjutnya, peneliti perlu membuka diri sebaik-baiknya dengan cara memanfaatkan metode-metode yang berbeda untuk mencapai tujuan penelitian dan melakukan diskusi yang intensif dengan orang lain tentang berbagai temuan dan analisis-analisis temuannya tersebut.

\section{KONFIRMABILITAS}

Konfirmabilitas (confirmability) diidentikkan untuk menggantikan konsep objektivitas dalam penelitian kuantitatif. Namun, Patton (1990) 
menganggap objektivitas tidak sama persis pengertiannya dengan yang dimaksud pada penelitian kuantitatif. Istilah konfimabilitas sama dengan penilaian obyektifitas pada penelitian kuantitatif ketika menekankan bahwa hasil temuan penelitian dapat dikonfirmasi/ dipresentasikan secara luas (Graneheim \& Lundman, 2004).

Objektivitas/konfimabilitas dalam penelitian kualitatif lebih diartikan sebagai konsep intersubjektivitas atau konsep tranparansi, yaitu kesediaan peneliti mengungkapkan secara terbuka tentang proses dan elemen-elemen penelitiannya sehingga memungkinkan pihak lain/peneliti lain melakukan penilaian tentang hasil-hasil temuannya. Beberapa peneliti kualitatif lebih mengarahkan kriteria konfirmabilitas mereka dalam kerangka kesamaan pandangan dan pendapat terhadap topik yang diteliti atau menitikberatkan pada pertanyaan sejauhmana dapat diperoleh persetujuan di antara beberapa peneliti mengenai aspek yang sedang dipelajari (Long \& Johnson, 2000).

Streubert dan Carpenter (2003) menjelaskan bahwa konfirmabilitas merupakan suatu proses kriteria pemeriksaan, yaitu cara/ langkah peneliti melakukan konfirmasi hasil-hasil temuannya. Pada umumnya, cara yang banyak dilakukan peneliti kualitatif untuk melakukan konfirmasi hasil temuan penelitiannya adalah dengan merefleksikan hasil-hasil temuannya pada jurnal terkait, peer review, konsultasi dengan peneliti ahli, atau melakukan konfimasi data/informasi dengan cara mempresentasikan hasil penelitiannya pada suatu konferensi untuk memperoleh berbagai masukan untuk kesempurnaan hasil temuannya.

Cara yang terakhir menurut Hammersley (1992) yaitu melakukan konfirmabilitas melalui presentasi hasil temuan kepada kalangan ilmiah yang memiliki kesamaan latar belakang/interested dalam suatu konferensi dapat memberikan berbagai manfaat, di antaranya dapat mencegah suatu premature closure dari pencarian suatu makna fenomena sosial yang dihasilkan dari hasil temuan penelitian tersebut. Penilaian konfirmasi hasil temuan studi kualitatif pada umumnya dilakukan bersamaan dengan pemeriksaan/ penilaian dependabilitas.

\section{PENUTUP}

Penilaian validitas dan reliabilitas data suatu penelitian merupakan suatu syarat yang harus dilakukan untuk menilai kualitas suatu hasil penelitian. Istilah validitas dan reliabilitas pada penelitian kuantitatif maupun kualitatif memiliki unsur kesamaan dalam prinsip-prinsip/standar umum. Namun, terdapat beberapa perbedaan dalam implikasi pengujiannya. Kredibilitas dalam penelitian kualitatif identik dengan validitas internal dalam penelitian kuantitatif; transferabilitas identik dengan aspek validitas eksternal dalam penelitian kuantitatif; dependabilitas identik dengan reliabilitas; dan konfirmabilitas identik dengan objektivitas.

Terdapat berbagai cara /langkah yang perlu dilakukan oleh para peneliti untuk memperoleh keabsahan/validitas dan reliabilitas data dalam penelitian kualitatif sehingga hasil-hasil temuan mereka dapat diyakini kebenarannya dan memiliki kekuatan dalam hal keakuratan data yang dihasilkan. Penilaian validitas dan reliabilitas dalam penelitian kualitatif meliputi penilaian kredibilitas, dependabilitas, transfermabilitas, dan konfirmabilitas (HH, JH).

* Staf Akademik Keperawatan Maternitas FIK UI

\section{KEPUSTAKAAN}

Brimk, P.(1991). Issues of retiability and validity. In Morse, J (ed). Qualitative nursing research: A contemporary dialogue. London: Sage, pp. 164-186.

Bungin, B. (2003). Analisis data penelitian kualitatif: Pemahaman filosofis dan metodologis ke arah penguasaan model aplikasi. Jakarta: PT Raja Grafindo Persada.

Graneheim, U. \& Lundman, B. (2004). Qualitative content analysis in nursing research: concepts, procedures, and measures to achieve trustworthiness. Nurse Education Today, 24, 105-112. 
Guba, E.G. \& Lincoln, Y.S. (1989). Fourth generation evaluation. Newbury Park: Sage Publications.

Hall, J. \& Stevens, P. (1991). Rigor in feminist research. Advances in nursing science, 13(3), 16-29.

Hammersley, M. (1992). What's wrong with ethnography? London: Routledge.

Long, T. \& Johnson, M. (2000). Rigour, reliability, and validity research. Clinical Effectiveness in Nursing, 4(1), 30-37.

Marshall, C. \& Rossman. (1995). Designing qualitative research. London: Sage Publications.

Morse, J.M. Barrett, M., Mayan, M., Olson K. \& Spiers, J. (2002). Verification strategies for establishing reliability and validity in qualitative research. International Journal of Qualitative Methods, 1(2), 1-19.
Patton, M. Q. (1990). Qualitative evaluation and research methods. Newbury Park: Sage Publications.

Polit, D.F. \& Hungler, B.P.(1995). Nursing research: Principles and methods. Philadelphia: Lippincott, PA.

Strauss, A.L. \& Corbin, J. (1990). Basic of qualitative research: Grounded theory procedures and techniques. Newbury Park: Sage Publications.

Streubert, H.J. \& Carpenter, D.R. (2003). Qualitative research in nursing: Advancing the humanistic imperative. $3^{\text {th }}$ (eds). Philadelphia: Lippincott, PA.

\section{RALAT}

Redaksi JKI menyampaikan permohonan maaf akan adanya ralat pada artikel yang dimuat di JKI volume 10, No. 2, September 2006 dengan judul:

PENGARUH ASAP ROKOK KRETEK TERHADAP IMUNITAS SELULER TIKUS BETINA STRAIN LMR (Rosila Idris, Hadi Hartanto)

Tercetak pada sub judul BAHAN DAN CARA KERJA paragraf kedua :

Selanjutnya kultur ditambahkan larutan hipotonik KCL 0,56\% untuk melisiskan sel dan selanjutnya diinkubasi selama 20 menit dengan suhu $37^{\circ} \mathrm{C}$. Proses selanjutnya ditambahkan larutan CARNOY 10 tetes kemudian disentrifus 10 menit sampai larutan jernih. Setelah jernih, larutan dibuat preparat dengan pewarnaan Giemsa 2\% dan dilihat pada pembesaran 40 kali dan 100 kali.

Seharusnya: Selanjutnya kultur ditambahkan larutan hipotonik KCL 0,56\% supaya sel-selnya tersebar dan kemudian diinkubasi selama 20 menit dengan suhu $37^{\circ} \mathrm{C}$. Proses selanjutnya ditambahkan larutan CARNOY 10 tetes untuk melisiskan sel darah merah kemudian disentrifus 10 menit sampai larutan jernih. Setelah jernih, larutan dibuat preparat dengan pewarnaan Giemsa 2\% dan dilihat pada pembesaran 40 kali dan 100 kali.

Semoga ralat ini dapat melengkapi pemahaman pembaca. Terima kasih. 